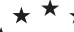

$\star$ Pollityki Europejskie.

$\star$ Finanse i Marketing

$\star \star \star 16(65) 2016$

Anna Świrska

Uniwersytet Przyrodniczo-Humanistyczny w Siedlcach

\title{
Czynniki determinujące efektywne zarządzanie finansami samorządowymi (na przykładzie gmin powiatu siedleckiego)
}

\section{DETERMINERS OF EFFECTIVE FINANCIAL MANAGEMENT OF LOCAL GOVERNMENTS (EXAMPLE OF MUNICIPALITIES OF SIEDLCE POVIAT)}

Zarzqdzanie finansami na szczeblu samorzqdowym jest procesem niezwykle złożonym, który wymaga zastosowania wielu narzędzi $i$ technik, $w$ celu jego optymalizacji. Wprowadzone $w$ ostatnich latach instrumenty, takie jak: budżet zadaniowy, Wieloletnia Prognoza Finansowa, czy Indywidualny Wskaźnik Zadtużenia maja na celu usprawnienie zarzqdzania finansami, jednak równie istotne wydaja się być odpowiednie kompetencje władz samorzadowych oraz kwalifikacje $i$ umiejętności pracowników.

Artykut przedstawia wyniki badań pilotażowych przeprowadzonych w samorzadach gminnych powiatu siedleckiego dotyczacych czynników wpływajacych na efektywność zarzadzania finansami lokalnymi. Badanie przeprowadzono w czerwcu 2016 roku wśród skarbników oraz osób petniqcych funkcje organu wykonawczego.

Celem artykulu jest próba określenia czynników determinujacych efektywność gospodarowania środkami finansowymi w gminach.

Slowa kluczowe: zarzqdzanie finansami, gmina, efektywność

\section{Wprowadzenie}

Termin efektywność zazwyczaj utożsamiany jest $\mathrm{z}$ rachunkiem ekonomicznym i oznacza wynik podejmowanych działań opisany przede wszystkim relacją osiągniętych efektów do poniesionych nakładów. Tak przyjęta definicja może mieć zastosowanie w sektorze prywatnym, w sferze produkcyjnej, gdzie zarówno efekty, jak i nakłady są łatwo mierzalne. Sensu largo pojęcie efektywności oznacza najlepsze rezultaty wynikające z prowadzonej działalności oraz skuteczność w realizacji zamierzonych celów (H.M. Coombs, D.E. Jenkins, 1994; B. Guziejewska, 2008). Tak rozumiana efektywność może mieć już zastosowanie w sektorze publicznym/samorządowym, gdyż pozwala ona zweryfikować sposób zarządzania daną JST i jej zasobami.

W kontekście zarządzania gminą szczególnego znaczenia nabiera zarządzanie finansami, jako kluczowy aspekt determinujący sprawne funkcjonowanie tej podstawowej jednostki samorządowej. Pojawia się tu problem związany nie tylko ze wskazaniem osób odpowiedzialnych za sytuację finansową (decyzje podejmuje organ stanowiący a wykonuje organ wykonawczy gminy; z kolei, osobą odpowiedzialną za przestrzeganie zapisów prawa i sprawująca kontrolę i nadzór nad całokształtem 
gospodarki finansowej $\mathrm{w}$ gminie jest skarbnik ${ }^{1}$ ), ale też $\mathrm{z}$ identyfikacją czynników determinujących efektywne zarządzanie finansami.

Przedmiotem badań były determinanty mające istotny wpływ na zwiększenie efektywności zarząadzania zasobami finansowymi w gminach. Wśród tych czynników poddano analizie m.in. narzędzia proponowane przez ustawodawcę: budżet zadaniowy, Wieloletnią Prognozę Finansową oraz Indywidualny Wskaźnik Zadłużenia.

Artykuł przedstawia wyniki badań pilotażowych przeprowadzonych w wybranych samorząach gminnych powiatu siedleckiego dotyczących analizy czynników wpływających na efektywność zarządzania finansami lokalnymi. Zastosowano metodę sondażu diagnostycznego $\mathrm{w}$ oparciu o narzędzie wywiadu pogłębionego i kwestionariusza ankietowego $\mathrm{w}$ technice badań ankietowych. Badanie przeprowadzono w czerwcu 2016 roku wśród osób pełniących funkcję organu wykonawczego, jako odpowiedzialnych za wykonanie budżetu, oraz skarbników, jako pracowników współpracujących z organem wykonawczym zwłaszcza w sferze finansowej. Ankietę przekazano drogą mailową lub wręczono osobiście przedstawicielom wszystkich gmin (14 jednostek), a respondentów zapewniono o anonimowości badań. Zwrotność wyniosła 64\% - otrzymano odpowiedzi od skarbników i wójtów z 9 gmin.

Celem artykułu jest próba określenia czynników determinujących efektywność gospodarowania środkami finansowymi w gminach.

\section{Efektywność zarządzania finansami w samorządach lokalnych - zarys problemu}

Analiza zarządzania finansami w sektorze publicznym w kontekście jego efektywności jest tematem ciagle aktualnym i nie do końca zbadanym. Po pierwsze, dlatego że trudno zmierzyć efekty w przypadku produkcji dóbr i świadczenia usług publicznych (Z. Fedorowicz, 1998, s. 122). Nie każde dobro publiczne lub usługa mogą być mierzalne, np. trudno zmierzyć działalność takich instytucji jak np. wojsko. Po drugie, precyzyjne oszacowanie skutków wydatków jest ograniczone ze względu na niedobór w procedurach budżetowych narzędzi i mechanizmów wiążących wydatki z ich efektami. Owszem, budżet zadaniowy, który jest wprowadzony na szczeblu centralnym posiada w swoich zasobach zbiór mierników, jednak ich wykorzystanie na szczeblu samorządowym niekiedy wymaga przekształcenia i dostosowania do indywidualnych potrzeb samorządów. Po trzecie, efekty niektórych wydatków występują z kilkuletnim opóźnieniem, co oznacza, że nie dysponujemy precyzyjnym rozkładem w czasie nakładów i efektów, a jest to niezbędne do właściwej oceny skuteczności zarządzania zasobami finansowymi (M. Poniatowicz, J. Salachna, D. Perło, 2010, s. 49). Niemniej jednak w wielu aspektach owa efektywność zarządzania finansami w sektorze publicznym mogłaby być większa, a wpływ na to powinna zwiększona jawność i przejrzystość procesów finansowych.

Od momentu decentralizacji finansów publicznych, wzrasta zainteresowanie efektywnością zarządzania na szczeblu lokalnym, co jest rezultatem coraz większej

\footnotetext{
${ }^{1}$ Potwierdzają to również przeprowadzone badania, w których $70 \%$ respondentów wskazało na skarbnika, jak osobę, która szczególnie odpowiedzialną za racjonalną gospodarkę finansową gminy
} 
liczby realizowanych zadań oraz wydawanych środków publicznych. Guziejewska i inni wymieniają następujące kierunki badań nad tym zagadnieniem (B. Guziejewska, 2008, s.71-73; M. Kosek-Wojnar, K. Surówka, 2005, s.173; S. Owsiak, 2002; W. Misiag, 2005; A.J. Kozłowski, 2012):

- efektywność funkcjonowania i realizacji zadań publicznych w kontekście źródeł ich finansowania,

- efektywność zarządzania usługami komunalnymi i gospodarka lokalną,

- uwarunkowania decentralizacji finansów publicznych i problemy samodzielności finansowej LGU,

- poszukiwanie fakultatywnych źródeł finansowania zadań publicznych,

- nowe metody i narzędzia planowania budżetowego,

- efektywność narzędzi i metod w procesach zarządzania finansami lokalnymi.

Efektywność zarządzania finansami w JST, rozumiana jako skuteczność realizacji celów i osiagania najlepszych rezultatów $w$ tej dziedzinie ${ }^{2}$ wynika przede wszystkim z zapewnienia (B. Nogalski, A. Świrska, 2016, s. 67):

a) dokładnego, przejrzystego i zrozumiałego zakresu kompetencji i obowiązków jednostek struktury organizacyjnej JST uczestniczących w procesie zarządzania finansami JST,

b) łatwego dostępu do aktualnych i rzetelnych informacji oraz do zrozumiałego systemu zarządzania informacjami,

c) efektywnego, jasnego, zrozumiałego systemu rachunkowości, sprawozdawczości, analizy i kontroli finansowej,

d) efektywnych systemów monitorowania działań organów władzy i jednostek organizacyjnych JST,

e) dostępu dla zarządzających i pracowników jednostek, będących obiektami zarządzania, do niezbędnych szkoleń oraz pomocy doradców.

Efektywność zarządzania finansami na szczeblu samorządowym jest więc wypadkową wielu czynników, a ich właściwa identyfikacja i umiejętność wykorzystania określa sprawność funkcjonowania danej JST. Nabiera to szczególnego znaczenia w przypadku gmin, które dysponując ograniczonymi zasobami realizują wiele zadań często wykraczających poza możliwości finansowe.

Celem wzmocnienia efektywnego gospodarowania środkami finansowymi ustawodawca wprowadza narzędzia, które w jego przekonaniu są skuteczne i wynika z nich szereg korzyści. Wymienić tu można chociażby budżet zadaniowy (fakultatywna forma planowania budżetowego), Wieloletnią Prognozę Finansową (obligatoryjny element uchwały budżetowej), Wieloletni Plan Inwestycyjny (obowiązek zniesiony w 2009 r.), Indywidualny Wskaźnik Zadłużenia (obowiązujący od 2014 r.). Niestety, jak wynika z badań (A.J. Kozłowski, 2012, s. 207) władze samorządowe sceptycznie odnoszą się do wprowadzanych narzędzi i nie upatrują $w$ nich instrumentarium przyczyniającego się do poprawy efektywności w sferze zarządzania finansami gminy.

\footnotetext{
${ }^{2}$ Dlatego, w artykule słowo efektywność jest często zastępowane słowem skuteczność
} 


\section{Determinanty efektywnego zarządzania finansami gminnymi - wyniki badań}

W opinii respondentów znaczenie dla efektywnego zarządzania zasobami finansowymi w gminach mają przede wszystkim kwalifikacje, umiejętności i cechy osób zaangażowanych $\mathrm{w}$ procesy finansowe. Taki wniosek nasuwa się po zapoznaniu się $\mathrm{z}$ odpowiedziami respondentów na pytanie dotyczące kwestii znaczenia poszczególnych determinantów dla poprawy efektywności zarządzania finansami w gminach.

W opinii osób pełniących funkcję organu wykonawczego najistotniejszymi determinantami skutecznego pozyskiwania dochodów, zwłaszcza tych zewnętrznych środków finansowych są kwalifikacje i umiejętności pracowników gminy w aplikowaniu o środki unijne (45\% wskazań). Na drugim miejscu wymieniono cechy charakteru osoby pełniącej funkcję organu wykonawczego, np. zaradność, przedsiębiorczość, komunikatywność (33\% wskazań). Wykształcenie i kwalifikacje organu wykonawczego uznano za trzeci w kontekście istotności czynnik (33\% wskazań). Ten sam odsetek respondentów uznał, że przynależność do rządzącej partii ma znaczenie dla skutecznego generowania zewnętrznych środków finansowych i umieścił ten czynnik na czwartym miejscu. Na ostatnim, piątym miejscu, umieszczono współpracę władz gminy $\mathrm{z}$ lokalnymi przedsiębiorstwami (w ramach partnerstwa publiczno-prywatnego) lub przynależność gminy do Lokalnych Grup Działania, a także znajomości i „układy” między władzami gminy a przedstawicielami innych JST (powiatu, województwa). Wprowadzenie Indywidualnego Wskaźnika Zadłużenia nie stanowi istotnego znaczenia dla skuteczniejszego generowania dochodów ze źródeł zewnętrznych w opinii organów wykonawczych.

Analizując odpowiedzi udzielone przez skarbników, wyłania się podobny katalog czynników, które mają wpływ na zwiększenie pozyskiwania zewnętrznych środków finansowych. Aż $67 \%$ respondentów tej grupy wskazało, że najistotniejsze są cechy charakteru osoby pełniącej funkcję organu wykonawczego. Na drugim miejscu znalazły się kwalifikacje i umiejętności pracowników gminy w aplikowaniu o środki unijne (33\% wskazań). $\mathrm{Na}$ trzecim miejscu umieszczono współpracę władz gminy z lokalnymi przedsiębiorstwami (w ramach partnerstwa publiczno-prywatnego) lub przynależność gminy do Lokalnych Grup Działania - 33\% wskazań. Indywidualny wskaźnik zadłużenia umieszczono jako przedostatni czynnik, tuż przed znajomościami i „układami” między władzami gminy a przedstawicielami innych JST (powiatu, województwa).

Efektywność gospodarowania środkami finansowymi w gminie to także racjonalne ich wydatkowanie. Aby usprawnić tę sferę zarządzania finansami w JST ustawodawca umożliwia planowanie budżetu w układzie zadaniowym oraz wprowadza Wieloletnią Prognozę Finansową i Wieloletni Plan Inwestycyjny, jednak jak wskazują przeprowadzone badania te narzędzia nie są postrzegane przez władze samorządowe jako kluczowe dla poprawy jakości procesów wydatkowania publicznych środków.

Analizując wyniki badań, wśród opinii wójtów wiodące są: odpowiedzialność finansowa władz gminy za nieracjonalne wydatki (33\% respondentów umieściło ten czynnik na pierwszym miejscu, a 45\% na drugim) oraz oszczędność władz gminy (45\% respondentów uznała ten czynnik za trzeci w kolejności). W kontekście racjonalizacji 
wydatków kwalifikacje i wykształcenie organu wykonawczego są czynnikiem, który $33 \%$ ankietowanych wójtów umieściło na czwartym miejscu, a kolejne 33\% - na piątym.

Odpowiedzi skarbników różnią się od opinii osób pełniących funkcję organu wykonawczego, niemniej jednak na pierwszym miejscu również wskazują na zasadność stosowania odpowiedzialności finansowej władz gminy za nieracjonalne wydatki (opinia 33\% respondentów). Wieloletnia Prognoza Finansowa została uznana jako czynnik bardzo istotny i umieszczona na drugim miejscu (33\% wskazań). Kolejne były wykształcenie organu wykonawczego (trzecie miejsce według 33\% respondentów), intensyfikacja kontroli wydatkowania środków publicznych (czwarte miejsce ex eaquo z aktywnym udziałem mieszkańców w planowaniu budżetowym). Na piątym miejscu skarbnicy umieścili wykorzystanie budżetu zadaniowego.

Reasumując, wyniki badań dotyczące czynników wpływających na efektywność zarządzania finansami w gminie sugerują, że kluczową rolę odgrywają kwalifikacje i wykształcenie pracowników oraz cechy charakteru osoby pełniącej funkcję organu wykonawczego. Ponadto, dla zwiększenia racjonalności wydatkowej istotne mogłoby być zwiększenie odpowiedzialności finansowej władz gminy za nieracjonalne wydatki.

W badaniach poddano też opinii wykorzystanie i skuteczność narzędzi proponowanych przez ustawodawcę, tj.: budżetu zadaniowego, Wieloletniej Prognozy Finansowej, Wieloletniego Planu Inwestycyjnego i Indywidualnego Wskaźnika Zadłużenia. Wbrew opinii ustawodawcy władze gmin nie są przekonane o skuteczności tych narzędzi w poprawie efektywności zarządzania finansami.

W związku z prowadzonymi badaniami nad transparentnością zarządzania finansami w gminach, szczegółowej analizie poddano budżet zadaniowy. Należy go rozumieć jako plan finansowy danej JST (zwłaszcza plan dotycząca części wydatkowej), w którym niezależnie od obowiązującej klasyfikacji budżetowej zapisane są konkretne zadania charakteryzujące się jednorodnością. Zadania te mają określone cele, koszty oraz osoby odpowiedzialne za wykonanie. Ponadto, co najważniejsze, w budżecie zadaniowym formułuje się mierniki, które oceniają nie tylko stopień realizacji danego zadania, ale również osoby i instytucje odpowiedzialne za realizację celów (A.J. Kozłowski, I. Z. Czaplicka-Kozłowska, 2014, s. 89 i n). Wdrożenie budżetu zadaniowego w samorządach gminnych wpłynęłoby nie tylko na ocenę skuteczności zarządzania finansami, ale również przyczyniłoby się do edukacji społeczeństwa w zakresie gospodarki finansowej samorządu (A.J. Kozłowski, 2012, s.208; A. J. Kozłowski,. Ekspertyza nr 1474/13A/UM/1 z dnia 05-06-2013 r.). Jest on niesłychanie istotny dla zapewnienia transparentności procesów finansowych w samorządach i tym samym zrozumienia treści uchwały budżetowej przez obywateli. Zalety budżetowania zadaniowego podkreśla wielu znawców tematyki finansów samorządowych (np. A.J. Kozłowski, Z. Gilowska, T. Lubińska, A.J. Kożuch, W. Misiag, E. Malinowska - Misiag), a także wynikają one z analizy doświadczeń takich państw: jak np. Francja, Słowacja, Nowa Zelandia. Niestety, jak wskazują wyniki przeprowadzonych badań władze naszych gmin mają odmienne poglądy na ten temat. Dokonując szczegółowej analizy skuteczności budżetu zadaniowego w opinii ankietowanych wójtów zauważyć można, że $78 \%$ wskazało na niewielką jego rolę w poprawie efektywności wydatkowania środków finansowych w gminach. 56\% jest zdania, że budżet zadaniowy w małym stopniu poprawia efektywność gospodarowania środkami finansowymi, a $22 \%$ - że wcale nie ma na to wpływu. $11 \%$ badanych wójtów nie ma zdania na ten temat. Jednocześnie $11 \%$ jest zdania, że budżet 
zadaniowy zwiększa efektywność zarządzania finansami w dużym stopniu. Opinie skarbników różnią się delikatnie od odpowiedzi wójtów. $22 \%$ skarbników jest zdania, że budżet zadaniowy zwiększa skuteczność zarządzania finansami. Taki sam odsetek respondentów $\mathrm{w}$ tej grupie uznaje budżet zadaniowy za zupełnie nieskuteczny. $45 \%$ skarbników jest dania, że budżet zadaniowy w małym stopniu przyczyna się do poprawienia skuteczności zarządzania środkami finansowymi (o $11 \%$ mniej niż w przypadku odpowiedzi wójtów). Takie odpowiedzi mogą wynikać z faktu, że żadna $\mathrm{z}$ gmin nie wprowadziła planowania w układzie zadaniowym, w związku z czym opinia nie wydaje się być uzasadniona realnymi przesłankami i konkretnymi doświadczeniami. Nieliczne odpowiedzi na pytanie: dlaczego ta forma planowania nie została wprowadzona wskazują na brak obowiązku budżetowania w formie zadaniowej w JST oraz na fakt, iż budżet gminy jest za mały, aby wprowadzać budżet zadaniowy. Niemniej jednak odpowiedzi na kolejne pytanie stanowią zaprzeczenie dla tezy, że obligatoryjność stosowania budżetu zadaniowego poprawiłaby sposób gospodarowania finansami w gminach. Aż 77\% skarbników i $89 \%$ wójtów jest zdania, że ów obowiązek nie zwiększyłby efektywności gospodarowania lub wpłynąłby na nią w niewielkim stopniu.

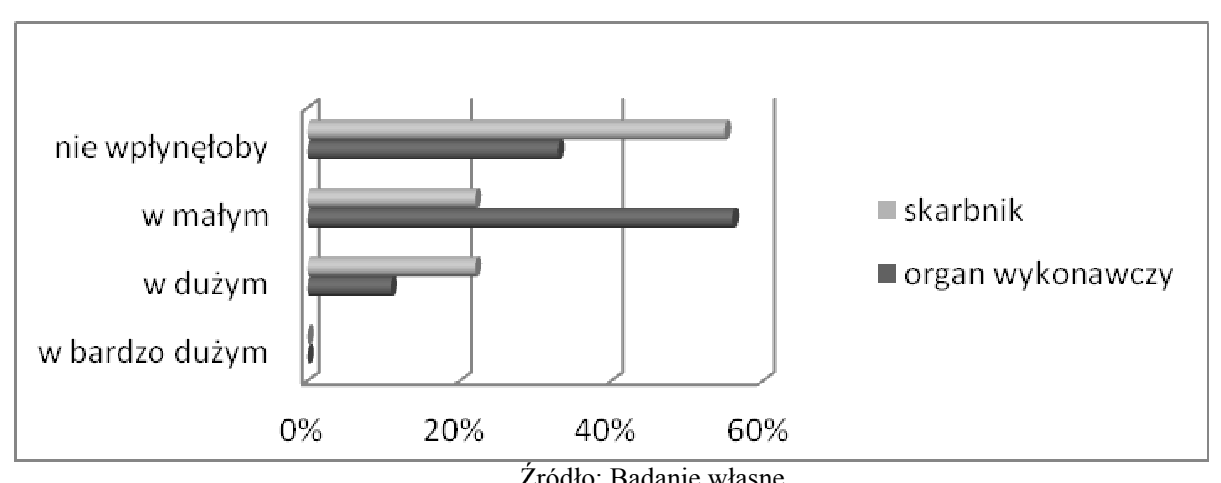

Wykres 1. Wpływ wprowadzenia obowiązku stosowania budżetu zadaniowego na efektywność gospodarowania środkami finansowymi w gminie

Zaskakujące (a może naiwne) są odpowiedzi na pytania dotyczące transparentności zapisów w uchwale budżetowej (czy w opinii Pana/Pani plan dochodów i wydatków jest czytelny i zrozumiały dla członków rady gminy oraz dla mieszkańców). Aż $89 \%$ respondentów wśród osób pełniących funkcję organu wykonawczego i 56\% wśród skarbników jest przekonana, że zapisy w budżecie rozumieją wszyscy radni, a $67 \%$ wójtów i $78 \%$ skarbników uważa, że budżet jest czytelny dla mieszkańców. Można przypuszczać, że opisowa część uchwały budżetowej jest względnie zrozumiała dla czytelnika, lecz wątpliwe jest czy zapisy klasyfikacji budżetowej są przystępne dla osoby nie posiadającej wykształcenia księgowego. Jak wskazują wcześniej prowadzone badania dotyczące transparentności ${ }^{3}$ zapisy klasyfikacji budżetowej są niezrozumiałe dla większości radnych i mieszkańców.

3 Szerzej: A. J. Kozłowski, Budżet w układzie zadaniowym w samorządach gminnych a transparentność zarządzania lokalnymi zasobami finansowymi. Znaczenie w procesie edukacji 
Zatem, zastanawiającym jest, czy władze samorządowe rzetelnie udzieliły odpowiedzi na pytania dotyczące budżetu zdaniowego. A może ich odpowiedzi są wypadkową niewłaściwej metody badawczej, obawy przed obowiązkiem wprowadzenia budżetu zadaniowego, braku wiedzy na temat skuteczności budżetu zadaniowego w zarządzaniu finansami gminy oraz lęku przed zwiększoną kontrolą społeczeństwa decyzji finansowych.

Prowadząc badania, wielu respondentów, zarówno wśród wójtów, jak i skarbników upewniało się, czy badania mają na pewno charakter anonimowy (mimo wcześniejszych zapewnień). Te obawy również mogą mieć wpływ na jakość udzielanych odpowiedzi. Strach skarbników przed ujawnieniem odpowiedzi organowi wykonawczemu oraz obawa wójtów przed udzieleniem odpowiedzi niepoprawnej politycznie mogą zniekształcać odpowiedz i stanowią podstawowy problem podczas badań prowadzonych w JST.

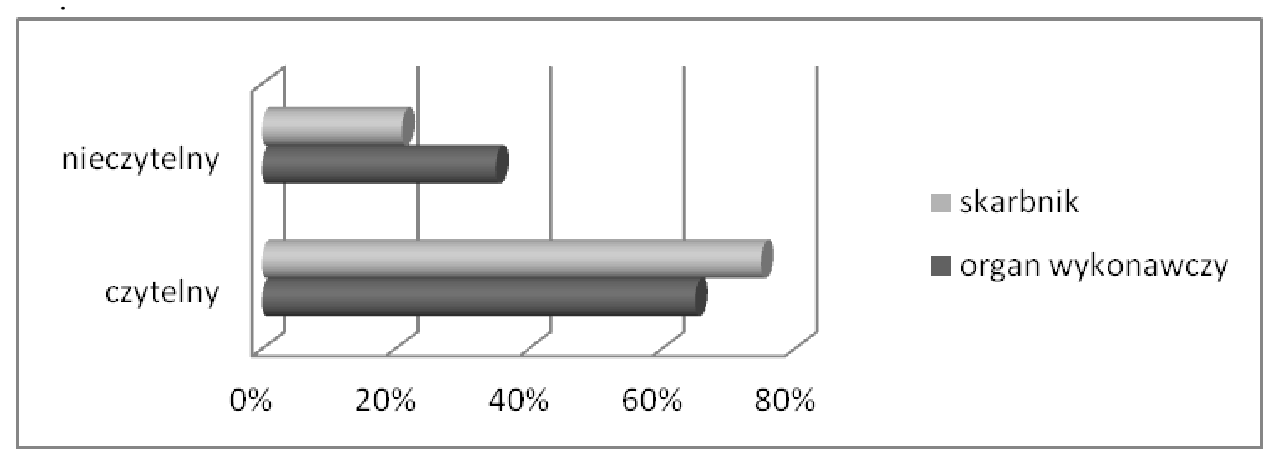

Wykres 2. Czytelność i zrozumiałość planu dochodów i wydatków dla członków rady gminy w opinii skarbników i wójtów

Źródło: Badanie własne

obywatelskiej o finansach publicznych. Ekspertyza nr 1474/13A/UM/1 z dnia 05-06-2013r. na zlecenie Kancelarii Sejmu RP; A.J. Kozłowski, I. Z. Czaplicka-Kozłowska, Transparentność zarządzania finansami lokalnymi. Uwarunkowania wdrożenia planu dochodów i wydatków w układzie zadaniowym, QNT Systemy Informatyczne, Kraków 2014; 


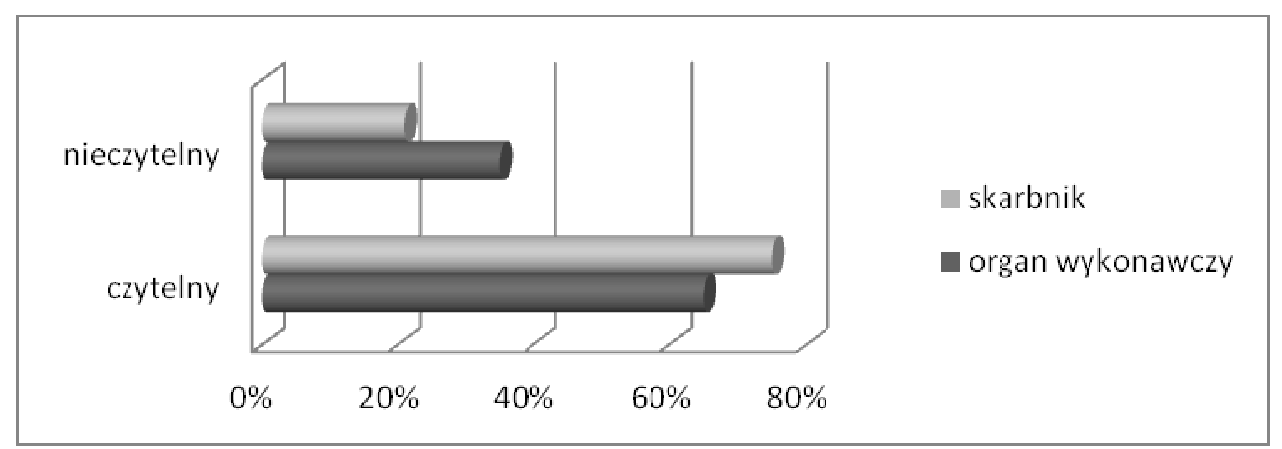

Wykres 3. Czytelność i zrozumiałość planu dochodów i wydatków dla mieszkańców gminy w opinii skarbników i wójtów.

Źródło: Badanie własne

Kolejnym narzędziem, które poddano opinii był Wieloletni Plan Inwestycyjny (WPI). Do roku 2009 był on obligatoryjnym dokumentem sporządzanym w JST, jednak ten obowiązek zniesiono i tylko w nielicznych gminach praktykuje się jego stosowanie. Jak wskazuje nazwa: Wieloletni Plan Inwestycyjny, dotyczy on długookresowej projekcji wydatków majątkowych, która umożliwia władzom właściwe skoordynowanie działań służących rozwojowi gminy.

Niestety nie wszyscy respondenci udzielili odpowiedzi na zadane pytania dotyczące WPI, co uniemożliwiło dokładne zbadanie tego zagadnienia. Jedynym spostrzeżeniem, jakie można zauważyć podczas analizy odpowiedzi na pytanie: czy w gminie wprowadzono Wieloletni Plan Inwestycyjny jest niezgodność, co do opinii organu wykonawczego i skarbników (np. 33\% wójtów jest zdania, że w ich gminie nie wprowadzono WPI, podczas gdy $56 \%$ skarbników potwierdza jego stosowanie).

Innym narzędziem zaproponowanym $\mathrm{w}$ celu poprawy skuteczności zarządzania finansami $w$ gminach jest Wieloletnia Prognoza Finansowa (WPF). Wprowadzona ustawą o finansach publicznych w 2009 roku ma na celu długofalowe i perspektywiczne spojrzenie na wydatki, zwiększenie transparentności decyzji finansowych i zaplanowanie rozwoju społeczno - gospodarczego gminy adekwatnie do posiadanych środków. Ponadto, kluczowym w WPF jest możliwość ustalenia priorytetów inwestycyjnych oraz zapewnienie ciagłości działań podejmowanych na terenie gminy (M. Jóźwiak, P. Walczak, U. Wiktorowska, 2010, s. 164;

K. Owsiak, http://www.ue.katowice.pl).

Jak wskazują wyniki badań w skuteczność WPF wierzy 78\% wójtów i 45\% skarbników, jednak dokonując oceny w jakim stopniu stosowanie WPF wpłynęło na poprawę racjonalizacji wydatków gminnych tylko $33 \%$ skarbników i $22 \%$ wójtów uważa, że wprowadzenie WPF wpłynęło korzystnie na jakość gospodarowania finansami w gminie. Gospodarowanie środkami finansowymi w gminie nie było wcześniej mniej racjonalne dla $45 \%$ wójtów i $67 \%$ skarbników. 


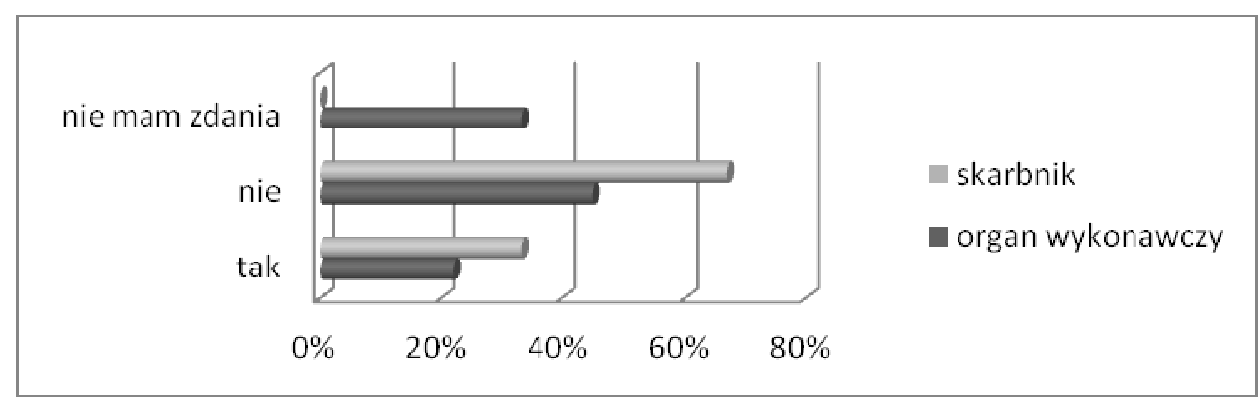

Wykres 4. Czy przed wprowadzeniem Wieloletniej Prognozy Finansowej gospodarowanie środkami finansowymi w gminie było mniej racjonalne?

Źródło: Badanie własne

Od 2009 roku gminy wiejskie mogą wydzielać w swoich budżetach fundusz sołecki (gminy miejskie - tzw. budżet obywatelski), którego zadaniem jest zwiększenie partycypacji społeczeństwa w planowaniu i realizacji wydatków. Uczestniczenie lokalnej społeczności w procesach decyzyjnych dotyczących sfery finansowej i realizacji przyjętych przez nich zadań stanowi jedno $\mathrm{z}$ najważniejszych narzędzi zarządzania $\mathrm{W}$ JST oraz jest warunkiem sprawnego zaspokajania potrzeb publicznych (B. Nogalski, J.M. Rybicki, 2006, s.153; A.J. Kożuch 2012, s.43). Poprzez swoją konstrukcję budżet obywatelski i fundusz sołecki powinny wpłynąć na lepsze gospodarowanie finansami w gminach. Jak wynika $\mathrm{z}$ badań w $89 \%$ analizowanych JST wprowadzono fundusz sołecki, jednak w opinii $67 \%$ ankietowanych skarbników tzw. budżety partycypacyjne nie wpływają na poprawę racjonalności gospodarowania finansami w badanych gminach. Tego samego zdania jest 33\% wójtów.

W celu poprawy zarządzania długiem w JST ustawodawca wprowadził w 2014 roku Indywidualny Wskaźnik Zadłużenia jako narzędzie mające służyć nadmiernemu zadłużaniu się niektórych gmin. Niestety brak odpowiedzi wielu respondentów uniemożliwił dokładną analizę przydatności tego narzędzia do poprawy efektywności zarządzania finansami. Zauważyć można jedynie, że mniej skłonni do udzielenia odpowiedzi na to pytanie byli wójtowie, co może wynikać z faktu braku dostatecznej wiedzy na temat obecnej i wcześniejszej zdolności kredytowej gminy.

Wychodząc z założenia, że jawność podejmowanych decyzji finansowych może oddziaływać na ich jakość, a tym samym na skuteczność zarządzania zasobami finansowymi, spytano respondentów w jakim stopniu konieczność upubliczniania informacji dotyczących planowania i wykonania budżetu wpływa na efektywność i racjonalność prowadzenia polityki wydatkowej w gminie.

Tylko 22\% wśród ankietowanych (zarówno wójtów, jak i skarbników) jest zdania, że upublicznianie informacji finansowych w dużym stopniu poprawia efektywność zarządzania finansami. Zdecydowana większość (56\% skarbników i 44\% wójtów) twierdzi, że nie ma wpływu. Jednocześnie, respondenci uznają zawartość biuletynu informacji publicznej w swoich gminach za wystarczającą i często uaktualnianą. Nie zawierają one niestety protokołów pokontrolnych (wszystkich) i tylko w jednej gminie, zgodnie z odpowiedziami, zamieszczany jest czytelny budżet, w formie opisowej. 


\section{Wnioski i rekomendacje}

Z przeprowadzonych badań dotyczących czynników determinujących poprawę efektywności zarządzania finansami w gminie można wyciągnąc trzy generalne wnioski:

- w opinii samorządowców wprowadzane przez ustawodawcę instrumenty służące poprawie gospodarowania finansami w gminach nie zawsze przynoszą zamierzone efekty,

- opinie pracowników podstawowej jednostki samorządu terytorialnego odbiegają daleko od założeń, jakie formułuje ustawodawca sprowadzając kolejne narzędzia dla poprawy zarządzania finansowymi środkami publicznymi,

- zdaniem samorządowców ważniejszą rolę w efektywnym zarządzaniu pełnią indywidualne cechy i umiejętności organów wykonawczych i pracowników urzędów gminy, niż tzw. „narzędzia twarde”,

Stąd, pojawiają się pytania dotyczące determinantów efektywnego zarządzania finansami w gminach:

- jakie narzędzia skutecznie mogą wpłynąć na poprawę efektywności w sferze gospodarowania środkami publicznymi,

- z czego wynikają rozbieżności między faktycznym wykorzystaniem obecnych narzędzi a założeniami ustawodawcy,

- dlaczego opinie praktyków (wójtów i skarbników) na temat budżetu zadaniowego, WPI, IWZ, WPF różnią się od założeń ustawodawcy.

Ponadto, co istotne dla dalszych badań, zauważyć można problemem, swoistej podwójnej moralności w ocenie transparentności zarządzania finansami publicznymi na najniższym szczeblu w strukturze państwa. Tym samym, pojawia się pytanie: $\mathrm{w}$ jaki sposób, faktycznie, władze samorządowe oceniają transparentność zarządzania finansami opierającą się o dotychczasowy układ wykonawczy budżetu oraz jakie narzędzia stosować w celu uzyskania rzeczywistej opinii na ten temat.

Efektywność, czy skuteczność, zarządzania finansami w sektorze samorządowym stanowi jedno z ważniejszych zagadnień dotyczących funkcjonowania samorządów lokalnych. Właściwe zarządzanie i gospodarowanie środkami finansowymi w każdej JST determinuje prawidłową realizację zadań i stwarza szansę na długotrwały rozwój społeczno-gospodarczego na jej obszarze. Stąd istnieje konieczność ciagłego monitorowania procesów i decyzji finansowych w gminach. Postulując pewne rekomendacje należałoby:

- wprowadzić obowiązek budżetowania zadaniowego w gminach, które poprawi transparentność gospodarowania finansami i umożliwi pomiar rezultatów podejmowanych decyzji finansowych,

- zweryfikować rzeczywisty system rekrutacji pracowników obsługujących organy gminy; wyeliminować nepotyzm i protekcję, a zatrudniać osoby o wysokich kwalifikacjach i doświadczeniu, wymaganym na danym stanowisku,

- „odpartyjnić” funkcję organu wykonawczego, stwarzając tym samym jednakowe szanse dla ubiegania się o zewnętrzne środki finansowe,

- wprowadzić zmiany $\mathrm{w}$ procedurze wyboru osób na stanowisko organu wykonawczego i baczniej spoglądać na ich wykształcenie i kwalifikacje w zarządzaniu w administracji publicznej. 
W kontekście dalszych badań nad efektywnością zarządzania finansami w gminach oraz wypracowaniem właściwej metody badawczej tej materii, należy:

- zapewnić pełną anonimowość badań. Kontakt osobisty lub drogą mailową nie jest odpowiednim sposobem prowadzenia badań wśród pracowników JST. Obawiają się oni ujawienia opinii, co wpływa na jakość odpowiedzi oraz ich rzetelność,

- opinie władz samorządowych warto konfrontować ze zdaniem mieszkańców, dlatego badania należy przeprowadzać nie tylko wśród władz samorządowych, lecz również wśród mieszkańców, a przynajmniej ich przedstawicieli w radzie gminy.

\section{Bibliografia}

Coombs H.M., Jenkins D.E., Public sector financial management, Chapman \& Hall, London 1994 Fedorowicz Z., Polityka fiskalna, WSzB, Poznań 1998

Guziejewska B., Efektywność finasów samorządu terytorialnego, Gospodarka Narodowa, 56/2008, Łódź 2008

Jóźwiak M., Walczak P., Wiktorowska U., Wieloletnia prognoza finansowa. Sporządzanie i uchwalanie, Municipium, Warszawa 2010

Kosek-Wojnar M., Surówka K., Dylematy racjonalizacji wydatków publicznych jednostek samorządu terytorialnego, (w:) J. Głuchowski, et al. (red.) Ekonomiczne i prawne problemy racjonalizacji wydatków publicznych, UMCS Lublin, 2005

Kozłowski A.J., Kwalifikacje radnych a zarządzanie zasobami gminy. Identyfikacja-diagnozakierunki zmian, Wyd. UWM, Olsztyn 2012

Kozłowski A.J., Czaplicka-Kozłowska I. Z., Transparentność zarządzania finansami lokalnymi. Uwarunkowania wdrożenia planu dochodów i wydatków w układzie zadaniowym, QNT Systemy Informatyczne, Kraków 2014

Kozłowski A. J., Budżet w układzie zadaniowym w samorządach gminnych a transparentność zarządzania lokalnymi zasobami finansowymi. Znaczenie w procesie edukacji obywatelskiej o finansach publicznych. Ekspertyza nr 1474/13A/UM/1 z dnia 05-06-2013r. na zlecenie Kancelarii Sejmu RP.

Kożuch A.J., Budżetowanie jako instrument zrządzania finansami jednostki samorządu terytorialnego, PWN, Warszawa 2012

Misiąg W., Wzorowy urząd, czyli jak usprawnić administrację samorządową, jak mierzyć jej zadania i wyniki, IBnGR, Warszawa 2005

Nogalski B., Rybicki J.M., Dialog społeczny jako forma i instrument podnoszenia sprawności zarządzania publicznego, (w:) B. Kożuch (red.), Problemy zarządzania organizacjami publicznymi, Fundacja WZiISP UJ, Kraków 2006

Nogalski B., Świrska A., Analiza wskaźnikowa jako narzędzie oceny kondycji finansowej i zarządzania finansami w gminie, (w:) A. J. Kozłowski, M.Cisek (red.), Samorząd gminny w Polsce. Czynniki determinujące rozwój lokalny. Wybrane problemy, Difin 2016

Owsiak K., Wieloletnia prognoza finansowa jako instrument zarządzania finansami jednostek samorządu terytorialnego,

http://www.ue.katowice.pl/fileadmin/_migrated/content_uploads/13_K.Owsiak_Wieloletnia_prog noza_finansowa..._01.pdf $(02.08 .201 \overline{6})$

Owsiak S., Budżet władz lokalnych. Narzędzie zarządzania, PWE, Warszawa 2002

Poniatowicz M., Salachna J., Perło D., Efektywne zarządzanie długiem w jednostce samorządu terytorialnego, Oficyna Wolters Kluwer Business, Warszawa 2010 


\section{Summary}

Financial management at local government level is an extremely complex process that requires the use of many tools and techniques in order to optimize it. Introduced in recent years, tools such as performance budget, Long-term Financial Forecast or Individual Debt Index aim to improve financial management, but the appropriate competences of local authorities and the qualifications and skills of the employees seem to be equally important.

The article presents the results of pilot studies carried out in municipal governments of Siedlce county on the factors determining the effectiveness of the management of local finances. The survey was conducted in June 2016 among main accountants and persons acting as the executive body.

The aim of this article is to develop a method and techniques of research of local finances management and to identify the factors determining the effectiveness of financial management in municipalities.

Keywords: financial management, municipality, effectiveness

\section{Informacja o autorze}

\section{Dr Anna Świrska}

Uniwersytet Przyrodniczo-Humanistyczny w Siedlcach

Wydział Nauk Ekonomicznych i Prawnych

Ul. Żytnia 17/19, 08-110 Siedlce

e-mail: annaswirska@gmail.com 